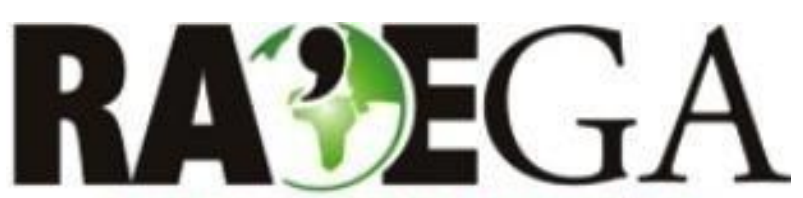

O ESPACCO GEOGRÁFICO EM ANÁLISE

\title{
GRILAGENS DE TERRA E CONFLITOS RURAIS: O LADO PERVERSO DA COLONIZAÇÃO NO PARANÁ
}

\section{GRILAGENSOFLANDANDRURALCONFLICTS:THEPERVERSESIDEOFCOLONIZATIONIN PARANÁ}

\author{
Elpidio Serra ${ }^{1}$
}

\section{RESUMO}

Grilagem de terras, quer através da falsificação de títulos de propriedade, quer através de outros mecanismos ilícitos, se constituiu em tarefa de fácil execução no Paraná, principalmente na fase da ocupação pioneira, ou seja, até o final da marcha colonizadora, nos anos 1960. No presente trabalho, um objetivo é destacar a facilidade com que os desvios de terras ocorreram, contribuindo para isso a estreita relação dos grileiros com o comando administrativo e com as lideranças políticas do Estado. Outro objetivo é associar as grilagens com os conflitos rurais, envolvendo o extermínio de camponeses, antigos ocupantes das terras griladas. Desvios de terras e conflitos vão caminhar lado a lado com a ocupação planejada do território, e no contexto da história agrária do Paraná, vão marcar o que pode ser chamado de o lado perverso da colonização. Em síntese o trabalho, sustentado em referenciais bibliográficos, em documentos oficiais e em informações extraídas de registros históricos, procura evidenciar o quadro de fraudes e de violência que marcou a ocupação e a apropriação das terras, tendo como recortes históricos o ano da emancipação política (1853) e o período em que se esgota o estoque de terras devolutas (década de 1960).

Palavras-chave: Desvios de terras; áreas devolutas; extermínio de camponeses; desorganização do espaço.

\section{ABSTRACT}

Land grab, orby falsifying titles of property, or through othermechanisms, if constituted in easy task running on the Paraná, mainlyat the stage of pioneering occupation, i.e. until the end of March, in the years 1960 colonizing. Inthe present work, a goal is to highlight the ease with which the land occurred, contributing to that the close relationship of the squatters with the administrative command and with the political leaders of the State. Another goal is to associate the grilagens with the rural conflicts, involving the extermination of peasants, former occupants of the land griladas. Misappropriation of land and conflicts will walk side by side with the planned occupation of the territory, and in the context of agrarian history of Paraná, will mark what may be called the perverse side of colonization. In summary, sustained work in official documents and on information extracted from historical records, seeks to highlight the frame of violence that marked the occupation and ownership of land, with historical clippings the year of political emancipation (1853) and the period in that depletes the stock of land Dole (early 1960).

Key-words: Misappropriation of land; dole areas; extermination of peasants; clutter the space.

Recebido em: 22/09/2017

Aceito em: 12/12/2018

\footnotetext{
1. Universidade Estadual de Maringá/Programa de Pós-Graduação em Geografia, e-mail: eserra@uem.br
} 


\section{GRILAGENS DE TERRA E CONFLITOS RURAIS: O LADO PERVERSO DA COLONIZAÇÃO NO PARANÁ}

\section{INTRODUÇÃO}

Pelo menos até o esgotamento das frentes de ocupação do território paranaense, que vai ocorrer na década de 1960, coincidindo com a etapa final do processo de colonização, 0 Paraná foi alvo de intenso e, pode-se dizer, contínuo processo de desvio de terras devolutas, sendo os mecanismos mais utilizados a grilagem, através da falsificação de títulos de propriedade; as concessões sob pretexto de colonização e de extração de recursos naturais, que nem sempre se concretizavam mas tiveram as áreas desviadas, e a apropriação de terras em pagamento de obras públicas, nem sempre executadas. Todos esses mecanismos, além de outros em menor escala, vão alimentar um vigoroso processo de desvios e apropriação irregular de terras e, ao mesmo tempo, vão se constituir em instrumento para a formação e consequente afirmação de uma poderosa oligarquia agrária no Estado, tendo como suporte, para se manter em atividade, estreitas ligações com o poder político dominante.

Paralelamente à apropriação irregular, os conflitos acontecem e não raras vezes transformam as frentes de ocupação e de colonização em espaços de violência, geralmente colocando frente-a-frente grileiros, agentes colonizadores e posseiros e via de regra resultando no extermínio dos posseiros. Saint-Hilaire (1932) explica como se davam os conflitos: "os pobres se estabeleciam nos terrenos aparentemente sem donos, construíam pequenas casas e iniciavam o cultivo. Subitamente surgia um homem rico portando o título que conseguira na véspera, expulsando-os e ainda se utilizando do fruto do seutrabalho"(SAINT-HILAIRE, 1932,p.38).

Resgate de dados históricos, sustentado em consultas de documentos dos acervos públicos e em análises de publicações relacionadas ao tema, permite afirmar que os mecanismos utilizados na prática dos desvios começaram bem antes da emancipação política do Paraná, em 1853, e se mantiveram até que a última porção de terras devolutas saísse do controle do Estado e passasse para o domínio de alguma colonizadora. Em alguns períodos, dependendo da facilidade ou da dificuldade para a atuação dos fraudadores, tendo do lado oposto as condições de resistência ou de fragilidade do setor público, os desvios são mais ou menos intensos, mas nunca deixando de existir. Existem situações, inclusive, em que fica complicado distinguir onde termina 0 campo de atuação dos fraudadores e onde começa o poder de decisão do Estado, dada a mistura de interesses entre os atores que militam no setor público e os atores que militam no setor privado: a conivência torna-se prática "social" e mantém caminho aberto para os desvios.

Na década de 1960 as fraudes na apropriação das terras perdem força e assumem a rota do desaparecimento, considerando-se apenas as fraudes que ocorriam na esfera do patrimônio público registros indicam que esgotado o estoque de terras devolutas, a ação dos fraudadores passou a mirar com mais intensidade as terras de terceiros. A redução e a consequente extinção da apropriação de áreas devolutas, a propósito, tem toda relação com o fim do estoque dessas áreas e nenhuma relação com alguma medida de repressão por parte do Estado. Sem mais terras para desviar, as quadrilhas, muitas vezes instaladas nas antessalas do poder, tendo com agentes públicos interesses comuns, passam a cobiçar outras terras, agora tendo como alvo áreas já colonizadas e lotes já comercializados pelas colonizadoras. Cidadãos comuns, principalmente camponeses, se transformam nas novas vítimas.

Durante todo o período de mais de cem anos, que começa a ser contado antes da emancipação política e vai até o esgotamento da marcha colonizadora, em que a prática de apropriação de terras devolutas foi recorrente, se existiu uma fase de trégua esta ocorreu na década de 1930 quando, em função de mudanças no comando político nacional (Getúlio Vargas assume como ditador a 


\section{GRILAGENS DE TERRA E CONFLITOS RURAIS: O LADO PERVERSO DA COLONIZAÇÃO NO PARANÁ}

presidência da República), o Paraná sofre um processo de intervenção e o comando político e administrativo do Estado sai das mãos de um governador eleito e passa para as mãos de um interventor federal. O primeiro interventor, e em seguida também o segundo interventor, sem ligações políticas com os grupos que tradicionalmente vinham atuando na apropriação de áreas devolutas, tiveram força suficiente para aniquilar a atuação dos grileiros e para recuperar boa parte das terras desviadas.

A fase "revolucionária" da década de 1930 inibiu os negócios dos fraudadores, mas não representou seu golpe de misericórdia, tanto que vencido o tempo de exceção política e administrativa, os desvios voltaram a acontecer. Mesmo não marcando o fim, e se caracterizando mais como "trégua", os anos 1930 podem ser utilizados como "divisores-deágua" no estudo da questão relativa à apropriação irregular de terras. E é desta forma, como marca de uma ruptura temporária, que a abordagem desse enfoque da questão agrária no Paraná é explorada no desenvolvimento do presente trabalho.

\section{MATERIAIS EMÉTODOS}

As fontes utilizadas para se resgatar os desvios de terra no Paraná, como foi citado, são basicamente registros e documentos oficiais. Referências bibliográficas são utilizadas, no sentido de contribuir para a interpretação dos fatos colocados em destaque. Importante ressaltar que na abordagem, as terras objeto do estudo são as classificadas como devolutas, ou seja, aquelas que em dado momento estão em poder do Estado, fazem parte do patrimônio público, mas ainda não têm fim específico definido podendo, portanto, serem destinadas à colonização. Extensas áreas desse patrimônio público vão se constituir no principal objeto de cobiça dos grileiros até 0 esgotamento das frentes colonizadoras, o que justifica o foco do estudo.

Considerando-se a colonização como mecanismo ou estratégia de organização do espaço, os processos de grilagem e de outras formas de desvios vão se constituir no lado perverso e ao mesmo tempo contraditório da organização espacial. Visto sob o ponto de vista da formação territorial e dos interesses envolvidos, tem-se na organização e contraditoriamente na desorganização do espaço, a territorialização da apropriação irregular de terras. Em sentido oposto a essa territorialização, tem-se a desterritorialização tanto das políticas públicas voltadas ao planejamento da ocupação humana e da apropriação legal das terras quanto dos atores sociais envolvidos na ocupação. É em função de tal lógica de raciocínio que o trabalho se apresenta estruturado enquanto procedimento metodológico, tendo como base de sustentação o resgate de fatos históricos.

\section{RESULTADOS EDISCUSSÃO}

\subsection{COMO FOI QUE TUDO COMEÇOU}

$\mathrm{Na}$ época em que o Paraná teve seu território desmembrado da Província de São Paulo, em 1853, as grilagens e outras formas de desvio de terrajá vinham acontecendo e eram facilitadas diante de um quadro montado artificialmente para atender aos interesses da oligarquia agrária, formada basicamente por latifundiários: em 1822 o primeiro governo do Império decretou o fim do acesso à terra através da concessão gratuita de sesmarias e só em 1850, portanto 28 anos depois, é editada a Lei de Terras (Lei 601), que vai estabelecer através da compra o novo mecanismo jurídico. Durante as quase três décadas de vazio jurídico, em que nenhuma legislação agrária vigorou para disciplinar o acesso àterra, éque vão surgir as chamadas grandes posses, dando uma sobrevida ao extinto regime de sesmarias. Latifundiários, estreitamente vinculados à antiga oligarquia agrária, se aproveitam da ausência de leis reguladoras e ampliam os limites de suas propriedades com terras griladas, com a certeza de que as posses seriam legalizadas, como de fato foram, quando surgisse a nova legislação. A Lei 601/1850, que em seu Artigo $1^{\circ}$ institui a mercantilização ao 


\section{GRILAGENS DE TERRA E CONFLITOS RURAIS: O LADO PERVERSO DA COLONIZAÇÃO NO PARANÁ}

estabelecer que "ficam proibidas as aquisições de terras devolutas por outro mecanismo que não seja o da compra" também reconhece em seu Artigo 4ำ 0 direito adquirido sobre as sesmarias, e no seu Artigo 5o reconhece como "propriedade legítima as posses mansas e pacíficas, adquiridas por ocupação primária...", ou seja: reconhece as terras griladas.

Emancipado politicamente em 1853, portanto três anos após a publicação da Lei de Terras, o Paraná, da mesma forma como as demais províncias do Império, teve que conviver e ainda dar suporte à legalização das grandes posses. Estabelecia o Artigo $5^{\circ}$ da Lei 601 que para o reconhecimento das posses como "propriedade legítima", a área apropriada deveria ser "registrada junto às repartições competentes". Ocorre que o Paraná não dispunha de legislação específica para o caso, nem dispunha de repartição pública em condições de verificar a autenticidade dos pedidos. A solução encontrada foi recorrer ao apoio da Igreja Católica para que a Igreja, em nome da autoridade pública, efetivasse os registros imobiliários como forma de reconhecer a posse como direito legítimo. Surge então o chamado "Registro do Vigário", instituído pelo Decreto 1318, de 1854, em que a responsabilidade pelos registros é transferida para a Igreja Católica, com plenos poderes. "As declarações de posse eram feitas em duas vias pelos interessados e entregues ao vigário, que fazia o registro, declarando numa das vias ou nelas certificando que o havia lançado no Livro. Estavia era entregueà parteea outra ficavano arquivo da paróquia. A via entregue era e é o que aparece agora como título de registro" (LACERDA, 1961, p. 1301).

O registro era para dar aspecto de legalidade às apropriações das terras que, tendo ocorrido num período sem lei, não se encaixavam no regime de sesmarias e tampouco era interessante para os beneficiados que fossem encaixadas no que estabelecia a Lei 601, que instituiu o mecanismo da compra. Problema resolvido? Nem tanto: as facilidades com que os vigários efetivavam a legalização das posses, longe de resolver o problema da titulação, passou a servir de estímulo a novos processos de grilagem, "visto que esse registro deveria ser feito mediante simples declaração dos próprios possuidores aos vigários das paróquias, não podendo estes recusar-se a fazê-lo, mesmo no caso de serem flagrantemente incorretas as declarações do suposto possuidor declarante" (SANTOS, 1983, p.49).

As condições favoráveis à apropriação de terras, e em seguida a sua legalização, acabam no curto prazo contaminando grupos políticos e econômicos que veem, no quadro criado e na fragilidade do setor público, uma nova oportunidade para o enriquecimento fácil, sem muito esforço, que se daria pela ampliação de seus domínios territoriais. A questão era aguardar o momento certo para agir.

Esse momento surge já nos primeiros anos do século $X X$, pouco tempo depois da República ser proclamada: o Paraná, agora Estado, abre as portas para o capital privado para, com ele, estabelecer um sistema de parcerias. As parcerias poderiam ocorrer em pelo menos duas situações: em projetos de colonização e em projetos para edificações de obras públicas, ambos se constituindo em estratégias para o deslocamento das frentes de ocupação humana. O Estado contava com as empresas para, "com sua experiência", construir obras estratégicas, principalmente no setor de transportes e planejar a ocupação humana, através da repartição e venda das terras e da infraestrutura necessária para 0 sucesso dos empreendimentos; as empresas, ou algumas delas, contavam com despreparo do setor público para burlar nos contratos firmados ou vender a custos elevados a "experiência" que o Estado estava precisando.

Nas negociações, sem recursos financeiros para arcar com os custos de sua parte, o Estado recorre ao seu estoque de terras devolutas e passa a usar essas terras, de forma direta ou indireta, como se fossem moeda corrente. Na forma direta, a empresa constrói a obra e recebe em terras; na forma 


\section{GRILAGENS DE TERRA E CONFLITOS RURAIS: O LADO PERVERSO DA COLONIZAÇÃO NO PARANÁ}

indireta, que vai prevalecer nos loteamentos, 0 Estado cede as áreas a preços simbólicos e em troca a empresa arca com os custos da infraestrutura e fica com os lucros obtidos na venda dos lotes urbanos e rurais. São transações aparentemente vantajosas para os dois lados: o Estado porque poupava recursos na organização do espaço pela colonização e nas construções das benfeitorias, que deveriam ser de sua responsabilidade e que ficavam por conta das empresas contratadas; as empresas porque recebiam as terras sujeitas a valorização no mercado imobiliário em condições altamente facilitadas, o que significava lucro certo.

Os problemas, no entanto, não demoraram para acontecer. No caso das parcerias no setor imobiliário, algumas loteadoras contratadas esperavam receber áreas desocupadas, desimpedidas, eemparteo que acabaram encontrando foram terras já griladas. As dificuldades, no caso a resistência dos grileiros, passaram a inviabilizar a execução dos loteamentos e as empresas, ou parte delas, decidem apelar para o já conhecido jargão popular: "se você não pode vencer o inimigo, junte-se a ele". Em outras palavras, terras griladas ganharam um segundo domínio, onde ficavam as empresas.

Com as obras contratadas e pagas com terras devolutas, o problema não foi diferente, comparado ao destino que tiveram as áreas destinadas para colonização ou para o extrativismo, na forma de concessão. Algumas loteadoras e grupos políticos se aproveitaram da fragilidade do Estado de manter sob controle a execução das obras contratadas, e acabaram não executando 0 que foi combinado, nem devolvendo as áreas alienadas nos contratos. Entre os casos registrados nessa situação de desvio, o que mais se destacou foi o da parceria feita pelo Estado e pela União com a empresa de capital inglês Brazil Railway Co., envolvendo uma área de dois milhões e cem mil hectares. $O$ contrato com a empresa inglesa previa a construção de uma estrada de ferro ligando São Paulo ao Rio Grande do Sul, na rota do antigo Caminho dos Tropeiros que cruzava o Paraná, e de um ramal que partindo do tronco principal da ferrovia fazia a ligação com o município de Guarapuava. O ramal era de interesse do governo do Paraná e o trecho principal da ferrovia era de interesse do governo federal, mas as terras alienadas para custear toda a obra estavam em território paranaense. Na época as faixas de fronteira, em todo o território brasileiro, eram consideradas áreas de segurança nacional e nessa condição estavam sob o domínio da União. Foi com terras localizadas nessa faixa que o governo federal pagou a sua parcela no contrato para a construção da ferrovia, considerada de importância como meio de transportes entre São Paulo e Rio Grande do Sul.

Nos termos do contrato, a empresa arcaria com o custo total das obras e receberia em troca o equivalente a nove quilômetros de terras de cada margem da ferrovia, em toda a sua extensão, o que inicialmente atingia uma área de um milhão e setecentos mil hectares, mas acabou atingindo dois milhões e cem mil hectares por meio de aditivos acertados entre as partes. A grande falha, que levou a transação a ser chamada de "a maior bandalheira da república": já no ato da assinatura do contrato, sem cláusulas de garantia, Estado e União titularam as terras em nome da contratada, ou seja, antes que as obras fossem iniciadas a empresa já era dona das terras. A União, titulando terras que alegava ser de sua responsabilidade por estarem em área de segurança nacional no Paraná e o Estado titulando terras devolutas, os dois lados dando voto de total confiança na empresa. A contratada, entretanto, não honrou o voto de confiança: abandonou as obras, mas ficou com as terras. Tempos depois, as terras griladas pela empresa inglesa voltam à cena como espaço de conflitos entre colonizadoras e camponeses e de disputas judiciais entre Estado e União, como será demonstrado em outro trecho deste trabalho. 


\section{GRILAGENS DE TERRA E CONFLITOS RURAIS: O LADO PERVERSO DA COLONIZAÇÃO NO PARANÁ}

\subsection{A RECUPERAÇÃO DAS TERRAS GRILADAS}

O quadro envolvendo grilagens, sob as mais variadas condições e situações, vai sofrer uma reviravolta no início da década de 1930 quando, em função da Revolução de 30 que levou Getúlio Vargas ao poder no comando da República, o governador do Paraná é deposto e em seu lugar assume um interventor federal. 0 interventor Mario Tourinho, logo após ser empossado, assinou o Decreto número 300 , em novembro de 1930, em que tornou nula a concessão da Brazil Railway e recuperou as terras alienadas no contrato, tanto as que que faziam parte do acordo com a União, quanto as que correspondiam à participação do Estado.

$O$ ato confiscatório do interventor paranaense, por atingir ao mesmo tempo e pelo mesmo Decreto as terras de domínio do Estado e da União, a propósito, vai alimentar complicados imbróglios políticos e jurídicos entre as duas esferas de poder. O jurídico foi porque o Governo Federal não reconheceu como de justo direito do Paraná a apropriação de áreas que, legalmente, não lhe pertenciam por estarem em zona de segurança nacional. A União contestou a legalidade do Decreto na parte que se referia à zona de segurança, admitindo, porém, o direito do Paraná às terras devolutas, que já faziam parte do patrimônio público estadual. O conflito de interesses vai motivar dois processos jurídicos no Supremo Tribunal Federal: um da União contra o Estado e outro do Estado contra a União.

De uma forma ou de outra, apesardos imbróglios gerados com a União o interventor Mario Tourinho adotou e manteve uma política de recuperação de terras desviadas, ou através de grilos, ou através de concessões fraudulentas, mesma política adotada pelo interventor que o sucedeu no cargo, sr. Manoel Ribas. "As medidas tomadas pelos interventores federais designados para 0 Paraná fizeram retornar ao patrimônio público todas as terras até então desviadas através da prática da grilagem e todas as terras objeto de concessões que por um motivo ou outro não estavam cumprindo as finalidades para as quais haviam sido outorgadas" (SERRA, 1991, p. 72).

Dados publicados pela historiadora Cecília Maria Westphalen (1968, p.14) indicam que apenas os vinte maiores grilos do Paraná haviam se apropriado, até a década de 1930, de 2.434.567 alqueires de terras, o equivalente a 6 milhões de hectares (um alqueire corresponde a 2,42 hectares no Paraná). Da Brazil Railway foram recuperados os dois milhões e cem mil hectares comprometidos no pagamento da estrada de ferro. De outras empresas, também contratadas para construção de obras públicas, principalmente ferrovias, e que igualmente receberam pagamentos em terras e não executaram os serviços contratados, foi recuperado um milhão de hectares, em números aproximados. No total, só das empresas retornaram ao controle do Estado mais de três milhões de hectares.

Somadas as áreas recuperadas de empresas contratadas para edificação de obras públicas, que não executaram as obras mas ficaram com as terras; as áreas entregues sob regime de concessão para extrativismo vegetal e mineral, que também acabaram sendo apropriadas vencido o período da concessão; as áreas entregues para colonização que não aconteceu, mas igualmente foram desviadas e ainda as áreas griladas pelo método convencional (falsificação de títulos de propriedade), os dois interventores conseguiram retomar para o controle do Estado aproximadamente 10 milhões de hectares. Os números são aproximados considerando que muitas das terras recuperadas eram contabilizadas como sendo áreas griladas e também como áreas de concessões fraudulentas porque incorporavam, ao mesmo tempo, as duas situações. Ou seja: áreas de concessões também estavam infestadas de grileiros e vice-versa. Constituíam, portanto, espaços que comportavam dois e até mais andares de desvios.

Efetivadas as desapropriações dos grandes grilos e das áreas entregues sob regime de concessão e que haviam se constituído em 


\section{GRILAGENS DE TERRA E CONFLITOS RURAIS: O LADO PERVERSO DA COLONIZAÇÃO NO PARANÁ}

mecanismo para desvios, o Estado amplia seu estoque de terras devolutas e passa a ter condições de dar novos rumos à política fundiária. No novo direcionamento, vai manter a colonização como estratégia de repartição e apropriação das terras, mecanismo que já era usado antes do período da intervenção federal no Paraná. A diferença não estava na estratégia, mas nas condições que os governantes passaram a ter para levar avante a reestruturação fundiária: como não foram eleitos, mas nomeados, estavam livres para impor medidas mesmo que consideradas antipáticas, do ponto de vista dos interesses da elite agrária, porque não deviam favores a ninguém.

A colonização poderia ser feita diretamente pelo Estado (a colonização oficial) ou por empresas credenciadas (a colonização empresarial privada) e para disciplinar a política colonizadora, o interventor Mario Tourinho editou o Decreto número 800, em agosto de 1931, estabelecendo em seu Artigo $1^{\circ}$ que as áreas consideradas devolutas "só poderiam ser adquiridas a título de compra, pelos que nelas se comprometessem a morar e estabelecer cultura efetiva". Para evitar que voltasse a ocorrer a concentração fundiária, o Artigo $5^{\circ}$ do mesmo Decreto fixava em duzentos hectares a área máxima que poderia ser adquirida por uma só pessoa.

Deve ser destacado que a nova política deu certo, pelo menos nos primeiros momentos, e isso se deve ao período de exceção a que estava submetida a administração pública. A boa fase, no entanto, era apenas transitória, o que significa que restabelecida a normalidade institucional os desvios poderiam voltar a acontecer, dependendo das condições que a categoria dos grileiros tivesse para reconquistar seu espaço nas esferas de poder. A propósito, destaca Serra (1991):

Os atos expropriatórios assinados pelos interventores representaram um duro golpe contra os grileiros de terra, mas não se constituíram em golpe de misericórdia, tanto que a categoria continuou agindo, embora daí em diante visando mais as terras de particulares e menos as terras devolutas. Os grileiros se infiltravam nas frentes pioneiras para extorquir terras de particulares e depois vender a preços elevados, repetindo depois a mesma operação, de preferência em outra área distante para não serem identificados (SERRA, 1991, p. 75).

\subsection{O RETORNO DOSGRILEIROS}

Retomadas as áreas apropriadas pelos grileiros e aquelas desviadas através de fraudes em projetos de colonização e de extrativismo, a colonização volta a ser o mecanismo indicado, em condições de contemplar tanto as metas em termos de organização do espaço, quanto as metas direcionadas ao desenvolvimento urbano e rural, que se daria como resultado da produção e circulação de riquezas nas frentes de ocupação. As duas metas seriam facilmente alcançadas, desde que o Estado dispusesse de meios para manter sob controle as empresas e os projetos por elas desenvolvidos e, logicamente, para manter os grileiros afastados de seu principal objeto de cobiça.

O Decreto 800 se constituía no instrumento que iria garantir o acesso à terra pela compra e limitar o tamanho máximo de cada lote, e ainda o instrumento que iria sinalizar a colonização como processo básico; como Decreto, entretanto, o documento não incorporava a força jurídica suficiente para delinear a política de relacionamento entre o Estado e o capital privado, representado pelas colonizadoras. Tendo em vista fortalecer as relações entre o público e o privado, é editada no ano de 1935 a Lei número 46, que estabelece: "Fica o Poder Executivo autorizado a promover a colonização das terras devolutas no Estado, mediante a concessão das glebas a empresas ou particulares, que assinarão contratos onde se estipularão cláusulas garantidoras dos interesses públicos e da fiel execução das condições da concessão" (LEI 46/1935, Artigo 1ㅇ).

O caminho estava novamente aberto para as colonizadoras, na condição de que se submetessem ao controle do Estado. Para agir, as empresas credenciadas não sofriam, naquele 


\section{GRILAGENS DE TERRA E CONFLITOS RURAIS: O LADO PERVERSO DA COLONIZAÇÃO NO PARANÁ}

momento, nenhum impedimento por parte dos grileiros, categoria que era considerada extinta pela ação dos interventores federais. Os pequenos posseiros é que vão se constituir em obstáculo nas áreas de colonização, porque criavam dificuldades à ocupação planejada. Algumas empresas tentam negociar amistosamente a saída dos posseiros; outras, no entanto, apelam para a violência, o que geralmente dá como resultado o extermínio dos ocupantes. A expulsão dos posseiros e também de indígenas, envolvendo ou não seu extermínio, é o que passou a ser chamada de "limpeza da área".

A presença de posseiros e indígenas nas áreas de colonização se constituía em pelo menos dois problemas para as colonizadoras em nome do sucesso do empreendimento: um era a dificuldade de vender terra ocupada difícil encontrar alguém disposto a comprar lote com gente já morando nele; outro era a dificuldade de planejar o loteamento, isolando áreas já habitadas. Duas situações consideradas indigestas por parte das empresas, e que também não eram toleradas pelo Estado. Segundo Costa (1975):

\begin{abstract}
A localização espontânea dos ocupantes de terras públicas, mediante o estabelecimento de atividade agrícola incipiente e de morada rústica, implicava na ocupação desordenada e crescente ampliação da área ocupada, numa consequente devastação sistemática, seleção das melhores terras, utilização das águas e de outras servidões, ocorrendo, inclusive, problemas no que se refere ao traçado perimétrico. Este sistema era totalmente contrário aos interesses do Estado, pois facilitava a devastação das melhores terras e o abandono das outras, depreciadas e desvalorizadas (COSTA, 1975, p. 821).
\end{abstract}

Para evitar, ou pelo menos amenizar os conflitos com os posseiros nas áreas entregues para as colonizadoras, o Estado através do Departamento de Geografia, Terras e Colonização (DGTC), criado em 1942, desenvolve um trabalho de cadastramento dos imóveis apropriados irregularmente nos últimos seis anos e de reassentamento dos ocupantes em áreas distantes. A preocupação aparente era preservar a integridade física dos camponeses, que antes eram ameaçados pelos grileiros e agora estavam sendo expulsos pelas companhias colonizadoras, interessadas em "limpar" a área para proporcionar aos futuros

compradores a garantia de que estavam adquirindo lotes livres de posseiros e indígenas.

Em linhas gerais, as diretrizes da política fundiária instituída pelo interventor Mario Tourinho e seu sucessor Manoel Ribas, estavam no seu curso normal, e foram mantidas sem muitas alterações, pelo menos durante os primeiros anos depois do período da intervenção federal. Estavam no seu curso normal, frise-se, porque esgotado o período de intervenção, a escolha do mandatário máximo do Estado volta a ser feita através de eleições diretas e em 1946 é eleito governador do Paraná o sr. Moysés Lupion. Político que nutria fortes ligações com os antigos grileiros, Lupion logo que assumiu o cargo criou a Fundação Paranaense para a Colonização e Imigração (FPCI) para dividir com o DGTC a condução da política fundiária. Como primeiro ato concreto, a Fundação assumiu a condução de um projeto de colonização na região Oeste do Paraná, desenvolvido em uma área de 450 mil hectares. O projeto deveria ser destinado ao assentamento de pequenos produtores rurais, expulsos das áreas das colonizadoras privadas, mas acabou se constituindo em nova porta aberta para o retorno dos grileiros, alguns camuflados decolonizadores.

\footnotetext{
Instituída em 1947 por Lupion, em seu primeiro mandato como governador, a FPCl funcionou para proteger os interesses privados e estaduais nas terras devolutas do Oeste de poderosos colonizadores como os Dalcanalle, tendo servido como mais um instrumento de especulação de terras apoiado pelo governador do Estado (FOWERAKER, 1982, p. 177).
}

\subsection{CAMPONESES: OU A TERRA OU A VIDA}

Moysés Lupion governou o Paraná entre 1946 e 1950 e foi eleito para cumprir novo mandato no período 1956-1960. Durante esses dois mandatos o Paraná viveu os seus 


\section{GRILAGENS DE TERRA E CONFLITOS RURAIS: O LADO PERVERSO DA COLONIZAÇÃO NO PARANÁ}

piores momentos de turbulência no setor agrário, envolvendo tanto a apropriação irregular de terras como a violência generalizada no campo, com o extermínio de camponeses. Mesmo em áreas de colonização planejada, onde as empresas cumpriam as metas estabelecidas nos projetos, a apropriação irregular acontecia e gerava conflitos.

Na região Norte, por exemplo, onde as frentes de ocupação eram atraídas pela qualidade das terras, consideradas propícias para o avanço das lavouras de café, as colonizadoras agiam de um lado e os grileiros do outro lado, tendo como ponto em comum a tarefa de expulsar os camponeses. No caso dos grileiros, não eram respeitados nem os camponeses que legalmente haviam se instalado em pequenos lotes mediante requerimento deferido pelo Estado.

\begin{abstract}
As terras eram requeridas legalmente do Estado; mas, os requerentes, eram obrigados a defendêlas contra o ataque brutal dos "grileiros" que, antes de se aproximarem de um posseiro, tinham o hábito de verificar, primeiro, se este estava morto (DUQUE ESTRADA, 1961, p.28).
\end{abstract}

A violência vai se constituir em marca registrada quando, o que está em jogo, é a disputa pela terra. Verificar primeiro se 0 camponês estava morto significa dizer que não havia luta porque os jagunços já chegavam atirando para matar e tomar "sem resistência" a terra ocupada. Os jagunços eram contratados pelos grileiros e se constituíam em "uma das melhores "coleções" de bandidos, facínoras e assassinos, egressos das cadeias e da justiça de todos os Estados" (DUQUE ESTRADA, 1961, p.30). Em outros termos, eram "profissionais do crime", contra os quais pouca chance de defesa tinham os camponeses.

Duque Estrada, a propósito, foi um dos poucos autores a vivenciar e a documentar a violência que marcou a ocupação do espaço agrário do Setentrião Paranaense, que na sua extensão coincide com a região Norte do Paraná, nas áreas banhadas pelos rios Ivaí
(Bacia do Médio lvaí) e Pirapó (Bacia do Pirapó). Afirma o autor, referindo-se aos grileiros e seus jagunços que atuavam na região: "Naquele tempo, o "avanço" nas terras devolutas do setentrião paranaense, transformara aquelas bandas em campos de luta violenta e, a mentalidade dos que ali se metiam, era avaliada em alqueires". E acrescenta: "A ordem e a posse e, porque não dizê-lo, a tranquilidade, eram mantidas por uma austera senhora chamada Winchester 44, amparada pelos Colts eW.S.38"(DUQUEESTRADA, 1961, p.30).

Arma de fogo, nenhum jagunço dispensava e fazia questão de deixar bem exposta na cintura, presa a um cinturão de balas, como que para intimidar quem passasse por perto. Armas e cinturão de balas faziam parte da indumentária dos bandidos. Do lado oposto, os camponeses, ou alguns deles, só podiam contar com espingardas de carregar pela boca, muito utilizadas na época para a caça; a maioria só dispunha de facas de cozinha ou facões para se defender. Mesmo dispondo de revólveres, nem sempre os jagunços utilizavam essas armas de fogo para aniquilar um camponês, preferindo outros métodos, com requintes de violência extrema, para "economizar balas". Ainda segundo Duque Estrada (1961, p.32):

\footnotetext{
A jagunçada tinha lá suas "leis" e suas maneiras de executá-las. Uma delas - as porungas consistia num modo esquisito de se livrar dos outros, sem gastar munição. Amarravam os braços do "cabra" para trás, colocando, em seguida, as "porungas" (cabaças do mato) bem presas nos joelhos ou nos pés, que ficavam bem amarrados. Jogado n'água, a cabeça do "bicho" vai ao fundo, enquanto, as "porungas", muito leves, flutuam juntamente com os pés, descrevendo, no começo, uma dança desesperada, macabros revolteios. Depois, lânguida e vagarosamente, vão descendo pelo rio, dando adeus à terra, que vai ficando atrás. Por seu lado, submisso ao seu destino, o "cabra" deixou de respirar (DUQUE ESTRADA, 1961, p.30).
}

Não se pode afirmar que todos os casos de violência nas disputas por terras 


\section{GRILAGENS DE TERRA E CONFLITOS RURAIS: O LADO PERVERSO DA COLONIZAÇÃO NO PARANÁ}

tiveram a participação, mesmo que indireta, do governador Lupion, nem se ele tinha conhecimento da extensão e da gravidade dos conflitos. O certo, no entanto, é que durante seus dois mandatos os grileiros não foram incomodados. Por outro lado, como reforço aos processos de grilagem, o sr. Lupion adotou o hábito de presentear amigos e correligionários políticos com terras devolutas, o que também vai se constituir em ingrediente para a violência no campo. Antes, o Estado pagava obras públicas com terras; agora, o governador usava as terras devolutas, portanto do Estado, para retribuir por favores políticos ou simples apoio à sua candidatura ou a candidaturas de correligionários durante campanhas eleitorais. O bem público utilizado em troca de favores políticos pessoais. Detalhe que chama atenção: a distribuição de terras era de tamanha dimensão que o próprio governador chegava a perder controle sobre as áreas presenteadas, tanto que existiram registros do mesmo lote ser doado a um aliado político e em seguida ser doado a outro aliado político. A dupla titulação voltou a fazer parte da rotina da questão agrária paranaense, agora sob uma ótica no mínimo curiosa, considerando a finalidade eleitoreira utilizada pelo governador.

A violência acompanhava a grilagem, uma como consequência da outra. Em alguns casos, os conflitos eram localizados eas marcas permaneciam restritas ao espaço onde ocorreram; em outros, no entanto, a dimensão era maior e extrapolava os limites do lugar. Dois conflitos ocorridos durante os governos do sr. Lupion ganharam destaque, tanto pelo número de envolvidos na condição de grileiros e posseiros, quanto pela área em disputa, um ocorrido na região Norte, que ficou conhecido como Guerra de Porecatu e outro ocorrido na região Sudoeste, que ficou conhecido como Levante dos Posseiros, o da Região Norte coincidindo com o primeiro mandato e o do Sudoeste coincidindo com o segundo mandato do sr. Lupion como governador do Paraná.

O conflito denominado Guerra de Porecatu, na prática, teve suas origens bem antes da posse do sr. Lupion para cumprir seu primeiro mandato, mas ganhou força total durante seu período de governo. No final do século XIX, quando as lavouras de café já evidenciavam sinais de decadência no Oeste do Estado de São Paulo em função do esgotamento dos solos e também em função da retração no mercado externo, fazendeiros paulistas se desfazem de seus bens naquele Estado, cruzam o rio Paranapanema que faz a divisa Paraná-São Paulo e se apropriam das terras sem dono no lado paranaense. A apropriação significava escolher a melhor área para formar uma nova lavoura de café, derrubar o mato e efetivar o plantio. Não se falava em comprar ou em vender terra, mesmo porque na época a zona visada pelos paulistas, banhada pelo rio Paranapanema no Paraná, não havia ainda sido colonizada. Era dono quem chegasse primeiro. Como as terras eram de boa qualidade para as lavouras de café, os fazendeiros paulistas não tiveram dúvidas em deixar para trás solos cansados e reiniciar a atividade em solos que, além de serem melhores, estavam disponíveis e sem custo a quem chegasse primeiro. A demarcação das posses era feita pelos próprios fazendeiros, como relata Wachowicz (1987):

\footnotetext{
Para eles, uma posse deveria equivaler a uma "água". Quem fazia a posse, procurava a cabeceira de um riacho. Instalado na cabeceira, é dono da água e do terreno que a acompanha até o fim. Essa posse ou água terminava quando esse riacho deságua num rio maior. No caso dos pioneiros de São José do Cristianismo, o ponto de partida para as primeiras águas foi o morro que existe na região. Do pico desse morro saiam até o Itararé três águas. Cada uma dessas águas dava origem a posses: Água da Pedra, Gabiroba e Grama (WACHOWICZ, 1987, p.81).
}

A princípio, o Estado tolerou a ocupação espontânea, mas quando o processo se intensificou, resolveu adotar medidas disciplinadoras. No sentido de frear a ocupação, na forma como vinha acontecendo, duas medidas foram tomadas, uma em sequência da outra: titular as terras já 


\section{GRILAGENS DE TERRA E CONFLITOS RURAIS: O LADO PERVERSO DA COLONIZAÇÃO NO PARANÁ}

apropriadas em nome dos fazendeiros e liberar as áreas restantes para o desenvolvimento de projetos de colonização. Em resumo: quem havia se apropriado de terras devolutas, tornase seu legítimo proprietário e quem ainda não havia se apropriado, agora teria que pagar pelos lotes colocados à venda pelas colonizadoras.

Um problema não demora para se manifestar: muitas das áreas tituladas em nome dos fazendeiros estavam também ocupadas por pequenos posseiros e como as duas categorias não conseguiram se entender, os camponeses passam a ser expulsos ou exterminados. Foi o começo da violência na região, que ganharia maior dimensão tempos depois, quando são dados os primeiros passos para os projetos de colonização, isto antes da década de 1930, época em que o Estado era refém de tradicionais desviadores de terras devolutas. Na colonização, o problema dos conflitos se agrava, não pelo modelo de repartição adotado, mas pela frustração da primeira tentativa envolvendo uma das empresas contratadas.

Quando O Estado, para frear a ocupação espontânea e disciplinar o acesso à terra na região abre espaço para a atuação das empresas, um dos grupos a se apresentar para a empreitada tinha como titular o sr. Antônio Alves de Almeida. A colonizadora do sr. Antônio recebe do Estado uma área de 300 mil hectares, onde deveria desenvolver um loteamento e assim atender à demanda dos produtores de café de São Paulo e agora também de Minas Gerais que se aventuraram em busca das terras de boa qualidade para as novas lavouras, no Paraná. $O$ projeto, no entanto, fracassa e como aconteceu com outros casos na época, as terras não foram devolvidas para o Estado. Em outras palavras: mais um caso de grilagem entrava na lista dos desvios de terra. Chega o período de intervenção federal no Paraná, na década de 1930, e os 300 mil hectares desviados pelo sr. Antônio foram recuperados, por força do Decreto 300 assinado pelo interventor Mario
Tourinho. Os 300 mil hectares faziam parte dos 10 milhões de hectares recuperados pelos interventores.

Do total da área retomada do projeto, 50 mil hectares foram destinados ao assentamento de posseiros que estavam em conflito com os fazendeiros paulistas. Os restantes 250 mil hectares permaneceram sem uma destinação definida, vencido o prazo da intervenção federal. Foi a válvula de escape, aproveitada por grileiros e por nova leva de cafeicultores, procedentes de São Paulo e de Minas Gerais. Como fizeram os outros que chegaram antes, os novos fazendeiros se apropriavam de uma área, desmatavam e formavam suas lavouras, na expectativa de conseguirem a titulação. Ocorre que a mesma coisa que faziam os fazendeiros e grileiros, também era feita por posseiros, com a diferença de que os primeiros se apropriavam de grandes áreas para especular ou para formar lavouras de café, enquanto os posseiros se instalavam em pequenas áreas onde formavam lavouras de subsistência e também plantavam alguns pés de café. Como a relação de vizinhança não era nada amistosa, o quadro de violência na região, longe de diminuir, só consegue aumentar.

É nesse contexto de violência, em que fazendeiros, grileiros e posseiros disputam a posse da terra, que o sr. Moysés Lupion é eleito para cumprir seu primeiro mandato como governador do Paraná. Um ano depois de tomar posse, em 1947, o governador visita a região e na tentativa de desarticular a resistência dos camponeses e de acabar com os conflitos promete doar a cada posseiro que saísse da área um lote de 10 hectares, com casa construída, mas bem distante dali, onde pudessem viver em paz. A terra prometida estava na região de Paranavaí, Noroeste do Paraná e muitos camponeses acreditaram, aceitaram a proposta do governador e abandonaram as posses, imediatamente incorporadas pelos fazendeiros e grileiros. Não demorou para descobrirem que haviam sido vítimas de um golpe aplicado pelo homem forte 


\section{GRILAGENS DE TERRA E CONFLITOS RURAIS: O LADO PERVERSO DA COLONIZAÇÃO NO PARANÁ}

do Paraná: a terra prometida não existia. "O não cumprimento do acordo, como é de se imaginar, dificultou entendimentos futuros, na medida em que solapou a credibilidade do poder público estadual" (REBELO, 2005, p.207).

Sem forças para enfrentar isoladamente os fazendeiros e perdendo suas posses, pelaviolência dosjagunçosepelogolpe aplicado pelo governador, os camponeses resolvem reagir de forma organizada $\mathrm{e}$ recorrem à ajuda das Ligas Camponesas, que atuavam principalmente no Nordestedo País.

\begin{abstract}
O emaranhado de grilos, títulos falsos, posse, especulação imobiliária e negociatas - comum no povoamento e colonização de novas fronteiras - acentuou-se nos anos 40 e gerou um quadro explosivo depois que colonos paulistas ocuparam terras improdutivas, e havidas como devolutas, para plantar café. Ameaçados por capangas de grileiros, os posseiros decidiram se organizar, como aconteceu nas localidades de Ribeirão do Tenente e Guaraci (REBELO, 2005, p.207).
\end{abstract}

A organização dos camponeses com a ajuda das Ligas Camponesas se opondo aos jagunços contratados pelos fazendeiros e grileiros teve, como resultado, a luta armada. Os conflitos se generalizaram em toda a região e dada a sua intensidade e a constância com que aconteciam, e também ao número de vítimas, despertaram a atenção dos meios de comunicação social, que passaram a dar ampla cobertura jornalística aos fatos. A revista " $\mathrm{O}$ Cruzeiro", considerada o veículo de comunicação impressa de maior importância na época, publicou uma série de reportagens relatando a gravidade dos conflitos, aos quais denominou de "Guerra de Porecatu", fazendo referência à cidade de Porecatu, onde eram planejadas as ações de expulsão dos posseiros. Nas reportagens, a revista de circulação nacional responsabilizou o governador Lupion pela gravidade da situação e apresentou o Norte do Paraná como "o eldorado onde as populações limpam a poeira penetrante do corpo com notas de mil cruzeiros; onde os hotéis cobram diárias exorbitantes; os garçons compram carros de luxo e o vendedor de caldode-cana ganha mais do que um Juiz de Direito" (OCRUZEIRO, dezembro de 1950, p.18).

A "Guerra de Porecatu" terminou em 1951 com a prisão de todos os líderes do movimento, principalmente os que tinham relação direta com as Ligas Camponesas, caso do esportista e radialista João Saldanha (técnico da Seleção Brasileira na Copa de 1970) e também com a retirada da zona de conflito de todos os posseiros. Entre os posseiros, foram distribuídos lotes de 15 e 20 hectares, mas não na própria região onde estavam suas posses e onde queriam ficar, mas sim bem distantes dali, na região Oeste do Estado. "As terras de primeira qualidade, apropriadas à cultura do café na zona de Porecatu, ficaram mesmo em poder dos fazendeiros" (SERRA, 1991, p. 149). Grileiros também tiveram terras tituladas nas zonas de conflito, como apadrinhados políticos do governador. $\mathrm{Na}$ época, em artigo publicado no jornal DIÁRIO DE NOTÍCIAS, de Curitiba, escreveu o jornalista Joel Silveira:

\footnotetext{
Nos últimos instantes de seu desastroso governo, o sr. Lupion resolveu confiscar e distribuir entre amigos e protegidos toda uma região do Paraná. Precisamente um pedaço da terra mais rica, que é a do Norte do Paraná. As misérias então se multiplicaram. Pequenos colonos, gente pobre e há tanto tempo no amanho da terra, viram-se de repente desalojados de seus tratos de chão. E lá chegavam, na terra cobiçada, os novos donos dela - protegidos e afilhados do governo, que traziam da capital, à guisa de termo de posse, os estranhos e capciosos documentos arranjados às pressas na capital. $\mathrm{O}$ assalto foi impiedoso $\mathrm{e}$ brutal. (SILVEIRA, 1951).
}

Outro conflito de grandes proporções, este coincidindo com o segundo mandato de Lupion como governador, aconteceu no Sudoeste do Paraná, tendo como palco parte das glebas retomadas da empresa Brazil Railway por ato do interventor federal Mario Tourinho na década de 1930. O conflito, denominado Levante dos Posseiros, se constituiu no desfecho de um complicado 


\section{GRILAGENS DE TERRA E CONFLITOS RURAIS: O LADO PERVERSO DA COLONIZAÇÃO NO PARANÁ}

imbróglio político e jurídico, envolvendo interesses do Estado, da União, das colonizadoras, dos posseiros e, evidentemente, dos grileiros que atuavam no Paraná.

Como foi destacado em outra parte deste trabalho, a empresa Brazil Railway havia sido contratada para a construção de uma ferrovia ligando São Paulo ao Rio Grande do Sul e de um ramal que, partindo do tronco principal da ferrovia, fazia ligação com 0 município de Guarapuava na região central do Paraná. O pagamento do tronco principal da ferrovia, bem como o ramal de Guarapuava foi feito com terras localizadas no Paraná, parte delas considerada devoluta, de responsabilidade do Estado e parte considerada como de domínio da União, por estar em área de segurança nacional.

A empresa não concluiu as obras e não devolveu as terras alienadas no contrato. Com a Revolução de 30, o governador do Paraná é deposto e quem assume o comando da administração pública foi o interventor Mario Tourinho que, num de seus primeiros atos confiscou todas as terras que estavam em poder da Brazil Railway, tanto aquelas de domínio do Estado quanto as que eram consideradas de domínio da União, surgindo a partir daí uma série de conflitos entre os dois poderes, nos campos político e jurídico.

Sem acordo entre as partes, as desavenças entre Estado e União foram parar no Supremo Tribunal Federal. O imbróglio político foi porque, antecipando-se à decisão do STF, o presidente da República, Getúlio Vargas, lança o programa Marcha para o Oeste, tendo como objetivo intensificar a ocupação do Oeste do País, deslocando para a região populações instaladas a Leste, basicamente em pequenas propriedades agrícolas classificadas como minifúndios. Entre as áreas visadas pelo programa estavam as terras em litígio no Sudoeste do Paraná, onde o Governo de Vargas instala, em 1943, a Colônia Agrícola Nacional General Osório (CANGO), que passa a receber e assentar reservistas e pequenos agricultores, basicamente originários do Rio Grande do Sul.

\begin{abstract}
A Colônia Agrícola Nacional General Osório, fora criada pelo Presidente Vargas em 12 de março de 1943, com o objetivo de promover a ocupação física da rica e extensa faixa de nossa fronteira, fixando nela, inicialmente, reservistas que haviam sido deslocados de seus afazeres rurais para prestação do serviço militar obrigatório e, posteriormente, outras famílias brasileiras que se comprometiam a observar as diretrizes emanadas do Departamento Nacional de Produção Vegetal, concernentes ao cultivo da terra, à demarcação das glebas, à proteção da flora, etc. (MARTINS, 1986, p.26).
\end{abstract}

A colônia agrícola serviu para o presidente Vargas como pretexto para retirar do Paraná o domínio sobre as terras da União. Ocorre que tanto sob a ótica jurídica quanto sob a ótica política, tal ato só poderia acontecer após a decisão do STF e no caso de a decisão ser favorável aos interesses do Governo Federal. A precipitação de Vargas acirrou os ânimos entre os dois níveis de poder e acabou afetando os colonos assentados, que sem a definição do STF quanto aos direitos do Estado ou da União sobre as terras do Sudoeste, não conseguiam titular os lotes que recebiam do Governo Federal. Outro resultado é que levas de camponeses, vindos principalmente do Rio Grande do Sul, uma vez não conseguindo lotes na Colônia Agrícola, passaram a abrir suas posses e ali se estabelecer em moradas rústicas e desenvolver suas lavouras de subsistência. No embalo da ocupação espontânea, grileiros camuflados de colonizadores, se aproveitam da indefinição sobre qual poder, se Estado ou União, era dono das terras retomadas da Brazil Railway e entram em cena para tirar vantagem. Um dos grupos, tendo fortes ligações com o governador Moysés Lupion, agora cumprindo seu segundo mandato, conseguiu constituir uma colonizadora, denominada Clevelândia Industrial e Territorial Limitada (CITLA), com a função de repartir e vender terras que não lhe pertenciam. Segundo Gomes (1987, p.35) e Martins (1986, p.309), a CITLA se credenciou para vender as terras ocupadas pelos colonos apresentando como prova documental uma escritura lavrada em cartório de registro de 


\section{GRILAGENS DE TERRA E CONFLITOS RURAIS: O LADO PERVERSO DA COLONIZAÇÃO NO PARANÁ}

imóveis que, curiosamente, foi aberto num dia, emitiu o documento e fechou as portas no dia seguinte. A empresa passa a forçar a venda das terras aos próprios ocupantes, quer na condição de colonos assentados na CANGO, quer na condição de posseiros, instalados em suas posses há pelo menos dez anos. Paralelamente à atuação da colonizadora, o sr. Lupion, repetindo o mesmo comportamento adotado no tempo do seu primeiro mandato, passa a distribuir terras entre correligionários políticos, em retribuição a apoio recebido durante a campanha eleitoral.

Em resumo: para a mesma área passaram a existir muitos "proprietários", mas nenhum portando 0 efetivo título de propriedade, que não poderia ser emitido enquanto o Supremo Tribunal não decidisse as pendências entre Paraná e União. A indefinição jurídica abre espaço para que a CITLA intensifique a pressão sobre os colonos e posseiros, na tentativa de forçar a venda dos lotes, emitindo como "garantia" de "direito de propriedade", recibos sem qualquer valor legal. Sem sucesso na empreitada (os camponeses sabiam que a colonizadora não tinha direito sobre as terras), a CITLA apela para a violência, contratando jagunços para expulsar os colonos e posseiros que se recusassem a comprar os lotes que, na prática, já lhes pertenciam.

Em 1957, a situação tornou-se insustentável no Sudoeste paranaense e atos de violência contra os camponeses, praticados pelos jagunços contratados pela colonizadora e pelos grileiros, eram constantes nos espaços que atualmente correspondem aos territórios dos municípios de Francisco Beltrão, Barracão, Pato Branco, Capanema e Santo Antônio do Sudoeste. Chega o final do ano e explode a reação camponesa: armados com espingardas de carregar pela boca, facões e ferramentas de trabalho, os trabalhadores invadem os escritórios da CITLA em Francisco Beltrão e destroem as instalações.

No dia 10 de outubro de 1957, cerca de 6.000 colonos tomaram a sede do município de Francisco Beltrão, no Sudoeste do Paraná.
Vinham em caminhões, carroças, a cavalo ou a pé. Todos armados. Com foices, velhos revólveres, espingardas de caça, enxadas e pedaços de pau. Concentraram-se na praça da Matriz, onde numa casa de esquina, ficava a estação de rádio local, transformada em centro de operações. A delegacia e a prefeitura foram tomadas - o prefeito e o delegado fugiram. $\mathrm{O}$ Juiz de Direito foi colocado em prisão domiciliar e o Promotor Público ficou sob a custódia do Exército até receber autorização para sair da cidade. (GOMES, 1987, p.9).

O governador nada pode fazer em represália porque, dias antes, havia recebido um ultimatum do Governo Federal: ou ele fechava a colonizadora e acabava com a violência, ou o Paraná sofreria nova intervenção federal, o que iria implicar na sua deposição do cargo.

\subsection{NA MIRA, AS TERRAS DE TERCEIROS}

Embora concentrados nas regiões Norte e Oeste, onde a ocupação humana foi mais intensa com reflexos na valorização das terras, na primeira região impulsionada pelos paulistas e mineiros e na segunda pelos gaúchos e catarinenses, difícil era encontrar no Paraná até a década de 1960, quando foi encerrada a marcha colonizadora, um espaço imune à apropriação irregular, que se dava pela prática da grilagem. Todo mecanismo que pudesse redundar na valorização das terras despertava a cobiça dos grileiros.

Vencida a fase da ocupação pioneira, que se marca pelo fim da marcha colonizadora, o Paraná começa a respirar um pouco de "paz agrária”, justificada pelo esgotamento do principal objeto de cobiça dos grileiros: a terra. Importante registrar que o "pouco de paz agrária" não vai sinalizar para o fim dos problemas fundiários, nem para o fim das grilagens, duas questões interligadas.

No que diz respeito às grilagens, sem as terras devolutas à disposição, os grileiros passam a mirar as terras de terceiros, utilizando-se do tradicional mecanismo da falsificação de títulos de propriedade (escrituras) e do seu "envelhecimento" forçado 


\section{GRILAGENS DE TERRA E CONFLITOS RURAIS: O LADO PERVERSO DA COLONIZAÇÃO NO PARANÁ}

para dar ao documento o aspecto de coisa antiga.

No que diz respeito aos problemas fundiários, a solução passa a depender do reconhecimento dos títulos cartoriais emitidos em grande parte a mando do governador Moysés Lupion. Vencido o período da colonização, os beneficiários começam a aparecer para fazer valer seus direitos de proprietários, e cada caso que aparece gera problemas na configuração da malha fundiária e eventualmente desencadeiam focos de conflitos. As duas situações acontecem na medida em que os lotes pleiteados, via de regra não têm medidas nem seus limites territoriais definidos, e em sua maior parte são ocupados por posseiros.

No Noroeste do Paraná, levantamento cartorial feito por Gonçalves (2004, p. 120), tomando por base apenas as terras doadas até o ano de 1948 e com menos de cinco mil hectares, apontou que trinta famílias foram beneficiadas com a doação de 214 lotes, totalizando 19.331,43 hectares, e que todas apareceram para regularizar direitos de propriedade, esgotada a marcha colonizadora. Lotes de maior dimensão, da mesma forma doados por Lupion a correligionários políticos, também passaram a ser reivindicados. Em um desses casos, relatado por Gonçalves (2004, p. 121), um "proprietário", desconhecido nos meios sociais do Noroeste, apareceu já na virada da década de 1950 para a década de 1960 paratomarposse de umaárea de 21.980 hectares, localizada no atual município de Querência do Norte, tendo em mãos um título assinado por Lupion. Quem se apresentou foi o sr. Tuffy Felício Jorge, descendente de migrantes sírios. Como a terra pleiteada estava ocupada por posseiros, o sr. Felício Jorge, para fazer valer seu direito de proprietário legítimo e ao mesmo tempo para se ver livre dos posseiros, resolveu formar pastagem para a criação de gado de corte. O resultado foi que, "com estas ações Felício Jorge entrou em confronto direto com dezenas de posseiros que há anos ocupavam a área" (GONÇALVES, 2004, p.121).

Frustrada a tentativa, entre o final dos anos 1960 e início dos anos 1970, Felício Jorge decidiu desmembrar a fazenda em duas: a Florão, na qual se manteve proprietário e a 29 Pontal do Tigre, com área de 10.896 hectares, que vendeu aos irmãos Jorge Wolney Atalla e Jorge Rudney Atalla, também descendentes de sírios. Os problemas, no entanto, não cessaram com a divisão e venda de parte da "propriedade", porque os posseiros resistiram para continuarem na área. Tem início aí um novo foco de conflito em disputapela posse da terra.

Paralelamente ao conflito que ocorria em Querência do Norte, no Noroeste, bem longe dali, na região Oeste do Paraná, outras formas de mobilização camponesa estavam acontecendo. No Oeste, cansados e ao mesmo tempo irritados com a morosidade com que o Governo Federal desenvolvia a reforma agrária no País, em função das metas estabelecidas no Programa Nacional de Reforma Agrária, e ainda aproveitando o ambiente político criado em função da inundação de áreas agrícolas para a construção do reservatório da Usina Hidrelétrica de Itaipu, trabalhadores rurais se organizam para fazer a reforma a partir das bases sociais. A mobilização camponesa consegue a organização da luta em torno de movimentos sociais (começa aí a história do MST, o Movimento dos Trabalhadores Rurais sem Terra, como órgão representativo) e logo em seguida a reforma agrária é desencadeada de baixo para cima, ou seja, a partir dos próprios trabalhadores, tendo como estratégia a ocupação de áreas improdutivas onde ocorriam conflitos rurais.

É neste contexto que as terras doadas por Lupion a correligionários políticos no Noroeste do Paraná acabam se transformando em alvo para novas ocupações. E o primeiro alvo a ser atingido, de certa forma inaugurando a atuação do MST na região, foi justamente o município de Querência do Norte e as terras originalmente pertencentes ao sr. Felício Jorge. 


\section{GRILAGENS DE TERRA E CONFLITOS RURAIS: O LADO PERVERSO DA COLONIZAÇÃO NO PARANÁ}

Em julho de 1988, a Fazenda 29 Pontal do Tigre é ocupada e em março de 1995, depois de sete anos de espera, acontece a desapropriação e a instalação do primeiro assentamento rural no Noroeste. Terras de grilo e terras desviadas acabam, enfim, tendo seu lado positivo na história agrária paranaense: só na Fazenda Pontal, 336 famílias foram e permanecem assentadas em 8.096 hectares.

\section{CONSIDERAÇÕES FINAIS}

Grilagens e outras formas de apropriação irregular de terras fizeram parte da história agrária do Paraná e, de certa forma, continuam fazendo. Não se pode afirmar, com segurança, que as fraudes na apropriação das terras constituem página virada na história agrária paranaense, mas com certeza as consequências geradas continuam vivas e quando emergem alimentam focos de conflitos no campo. Afinal, não é por acaso que boa parte das ocupações de terras capitaneadas pelos movimentos que lutam pela reforma agrária, o MST em especial, miram as áreas que não apresentam um passado histórico confiável, quando se trata da forma como foram apropriadas.

A retrospectiva histórica produzida neste trabalho ajuda a refletir sobre a intensidade e as formas como as fraudes ocorreram, levando em conta principalmente a fase que se esgota nos anos 1960, quando se dá o encontro das frentes de ocupação e quando chega ao fim o estoque de terras devolutas que poderiam ser destinadas à colonização empresarial. Pelo menos duas situações ficam evidenciadas: uma é que a apropriação irregular de terras teve, em boa parte, a participação direta de grupos políticos instalados no comando administrativo do Estado; outra é que os desvios geraram conflitos e custaram vidas humanas, principalmente de camponeses. Juntando as fraudes e os conflitos, é que foi desenhado $o$ lado perverso da colonização paranaense, quer a desenvolvida pelo próprio Estado (a colonização oficial), quer a desenvolvida pela iniciativa privada (a colonização empresarial privada). Em outros termos, ao lado de projetos colonizadores bem estruturados, em que para ser dono da terra era preciso pagar por ela, caminhou a apropriação irregular, em que para ser dono não era preciso pagar. Bastava ter ligações com grupos políticos ou dispor de tropas particulares, compostas por jagunços bem armados, prontos para expulsar e para matar. Saint-Hilaire tinha razão quando, na década de 1930, ao visitar o Paraná e tomar conhecimento das atrocidades, publicou: "Os pobres se estabeleciam nos terrenos aparentemente sem donos, construíam pequenas casas e iniciavam o cultivo. Subitamente surgia um homem rico portando o título que conseguira na véspera, expulsandoos e ainda se utilizando do fruto do seu trabalho".

\section{REFERÊNCIAS}

BRASIL.Governo do Império. Lei 601/1850 (Lei de Terras. Dispõe sobre as terras devolutas do Império). Rio de Janeiro: Governo do Império, 18, set. 1850. Disponível em:www.planalto.gov.br/ccivil. Acesso em: 18 de março de 2017.

BRASIL. Governo do Império. Decreto 1318/1854 (Dispõe sobre as terras devolutas do Império e institui o Registro do Vigário). Rio de Janeiro: Governo do Império, 05, nov.,1854. Disponível em: www.planalto.gov.br/ccivil. Acesso em: 18 de março de 2017.

COSTA, O. R. G. Planos de colonização oficial aplicados a partir da década de 1930, em zonas pioneiras e de povoamento, no Estado do Paraná. In: SIMPÓsIO NACIONAL DOS PROFESSORES UNIVERSITÁRIOS DE HISTÓRIA, XVIII, 1975. Aracaju: Universidade Federal de Sergipe, 1975, Anais, p.817-841.

DUQUE ESTRADA, J. F. Terra Crua. Curitiba: s.ed., 1961.

FOWERAKER, J. A luta pela terra: a economia política da fronteira pioneira no Brasil de 1930 aos dias atuais. Rio de Janeiro: Zahar Editores, 1982.

GOMES, I.Z. 1957: a revolta dos posseiros. Curitiba: Criar Edições, 1986. 
GONÇALVES, S. O MST em Querência do Norte-Pr.: da luta pela terra à luta na terra. 2004. Dissertação (Mestrado em Geografia) - Programa de PósGraduação em Geografia, Universidade Estadual de Maringá.

MARTINS, R. S. Entre jagunços e posseiros. Curitiba: Studio GMP, 1986.

OCRUZEIRO, revista. Rebelião no Paraná - sangue na terraproibida. Rio de Janeiro:p.18-24, dez., 1950.

PARANÁ. Lei 46/1935 (Define a relação entre Estado e colonizadoras). Curitiba: Diário Oficial do Estado do Paraná, 10 dez., 1935. Disponível em: www.legislação.pr.gov.br. Acesso em: 10 de dezembro de 2016

PARANÁ. Decreto 300/1930 (Confisca as terras da empresa Brazil Raillway). Curitiba: Diário Oficial do Estado do Paraná, 03 nov.1930 Disponível em: www.legislação.pr.gov.br. Acesso em: 10 de dezembro de 2016

PARANÁ. Decreto 800/1931 (Estabelece normas para a aquisição de terras) Curitiba: Diário Oficial do Estado do Paraná, 08, abr.,1931. Disponível em: www.legislação.pr.gov.br. Acesso em: 17 de dezembro de 2016.

REBELO, V. Bento Munhoz da Rocha: o intelectual na correnteza política. Curitiba: Imprensa Oficial, 2005.

SANTOS, D. Sesmarias: terras devolutas e registros paroquiais. Revista de Direito Agrário, Brasília: INCRA, p.42-49, 1983

SAINT-HILAIRE, A. Segunda viagem do Rio de Janeiro a Minas Gerais. São Paulo: Editora Itatiaia, 1932.

SERRA, E. Processos de ocupação e a luta pela terra agrícola no Paraná. 1991. Tese (Doutorado em Geografia) - UNESP. Rio Claro.

SILVEIRA, J. 0 desastroso governo Lupion. Curitiba: Diário de Notícias, jornal, 5 jun., 1951.

WACHOWICZ, R. Norte Velho, Norte Pioneiro. Curitiba: Editora Vicentina, 1987.

WestPlalen, C. M. Nota Prévia ao estudo da ocupação da terra no Paraná moderno. Boletim da Universidade Federal do Paraná, Curitiba, n.7, p.1-52, 1968. 